\title{
Estimasi Tekanan Formasi menggunakan Metode Tekanan Efektif dan Tekanan Minimum dengan Kalibrasi Data Log (DST, RFT, FIT dan LOT): Studi Kasus Lapangan NN\#
}

\author{
Anis Berry dan Widya Utama* \\ Laboratorium Geofisika, Jurusan Fisika, FMIPA \\ Institut Teknologi Sepuluh Nopember \\ Kampus ITS Sukolilo, Surabaya 60111
}

\begin{abstract}
Intisari
Tekanan formasi ditimbulkan oleh tekanan fluida yang terperangkap dalam formasi. Pada umumnya, tekanan formasi dibedakan menjadi tiga golongan yaitu tekanan hidrostatik, tekanan rekah (fracture gradient) dan tekanan batuan (overburdent pressure). Kajian ini merupakan aplikasi metode tekanan efektif dan metode tekanan minimum untuk memperoleh estimasi terbaik nilai tekanan formasi dan dan memahami karakteristik respon log sonic \& gamma-ray terhadap perubahan litologi. Asumsi yang digunakan adalah nilai tekanan pori normal (tekanan hidrostatik) sebesar $0,465 \mathrm{psi} /$ feet dan tekanan overburden $1 \mathrm{psi} / \mathrm{feet}$. Estimasi dilakukan pada 3 sumur, dengan hasil tekanan pori maksimum 13 ppg dan tekanan rekah maksimum 17 ppg. Tekanan pori maksimum (overpressure) terjadi di kedalaman 6000ft untuk sumur 1 dan $5200 \mathrm{ft}$ untuk sumur 2 dan 3. Berdasarkan respons log (kualitatif analisis), diperkirakan terdapat hidrokarbon dengan reservoar yang diduga berupa batuan karbonat pada kedalaman 5800 feet pada sumur 1 dan kedalaman 5000 feet pada sumur 2 dan 3 .
\end{abstract}

KATA KUNCI: estimasi tekanan pori, tekanan rekah, tekanan minimum, tekanan efektif.

\section{PENDAHULUAN}

Tekanan formasi merupakan suatu gaya yang ditimbulkan oleh tekanan fluida yang terperangkap dalam formasi. Fluida ini diasumsikan berkesinambungan dari permukaan sampai pada dasar sumur, sehingga pada setiap level formasi sampai bagian bawah sumur dapat diketahui besarnya tekanan formasi yang biasa juga disebut sebagai tekanan reservoir. Tekanan formasi dikategorikan menjadi 2 yaitu tekanan pori yang merupakan tekanan oleh fluida yang terdapat didalam ruang pori batuan, serta tekanan rekah adalah tekanan yang menyebabkan retakan pada dinding batuan formasi. Dengan kata lain bila batuan formasi mendapat tekanan melebihi batas tekanan rekah, maka formasi akan pecah.

Tekanan formasi adalah hal yang sangat penting dalam eksplorasi/eksploitasi minyak dan gas. Tekanan formasi dapat digunakan sebagai acuan dalam perhitungan rekayasa dan produktivitas reservoir. Selain itu, data ini sangat diperlukan dalam proses rekayasa pemboran seperti proses penentuan kedalaman pemasangan selubung. Banyak akibat yang ditimbulkan dalam pemboran yang disebabkan oleh kesalahan dalam prediksi tekanan formasi, seperti blow-outs dan lost circulation. Terdapat juga akibat samping lainnya seperti terjadinya ketidakstabilan pada lubang bor. Oleh karena itu, prediksi kwantitatif tekanan formasi sangat dibutuhkan demi

\footnotetext{
*E-MAIL: widya@physics.its.ac.id
}

keamanan dan keselamatan pemboran. Lebih dari itu, diharapkan tidak terjadi hal-hal diluar perencanaan akibat kesalahan prediksi sehingga nilai ekonomis dan produktifitas sumur akan terjaga.

Pembahasan permasalahan dalam laporan ini dibatasi pada estimasi tekanan formasi yg meliputi tekanan pori dan tekanan rekah. Estimasi tekanan pori dilakukan dengan menggunakan metode tekanan efektif horizontal Eaton dan Weakley, sedangkan estimasi tekanan rekah menggunakan konsep metode tekanan minimum dengan metode Hubbert \& Willis, Eaton, dan Daines. Sumber data yang digunakan adalah data log sonic dan log gamma-ray yang didukung dengan data log resitivity dan log caliper sebagai data informasi bantuan. Sebagai asumsi dalam estimasi digunakan $1 \mathrm{psi} /$ feet untuk gradien overburden dan $0,465 \mathrm{psi} /$ feet sebagai nilai gradien tekanan pori normal.

\section{DASAR TEORI}

\section{A. Kompaksi Sedimen}

Pada awalnya, sedimen tidak terkonsolidasi dan memiliki porositas serta permeabilitas yang tinggi. Sehingga, air yang berada di ruang pori batuan behubungan langsung dengan tekanan di permukaan dan berat fase padat yang didukung oleh hubungan antar butir batuan dan tidak berpengaruh pada tekanan fluida [1]. Tekanan pori $p$ di dalam fluida diberikan oleh tekanan hidrostatik kolom air yang berhubungan den- 


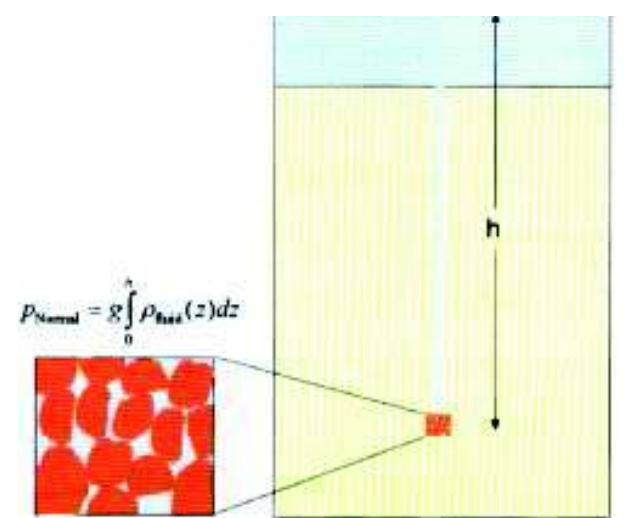

Gambar 1: Sedimen dalam keadaan tekanan normal [1]

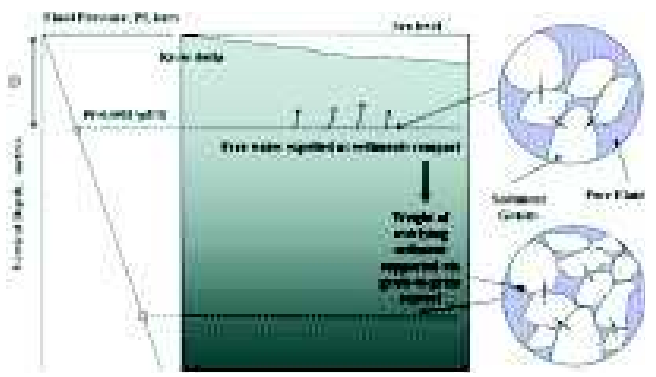

Gambar 2: Tekanan hidrostatik selama kompaksi normal [2]

gan permukaan (Gambar 1). Sedimen dengan tekanan pori yang sama dengan tekanan hidrostatik disebut dalam keadaan tekanan normal (normal pressure). Tekanan normal pada kedalaman $\mathrm{h}$ dari permukaan laut diberikan oleh

$$
p_{\text {Normal }}(h)=g \int_{\circ}^{h} \rho_{\text {fluid }}(z) d z
$$

dengan $g$ adalah percepatan gravitasi dan $\rho_{\text {fluid }}(\mathrm{z})$ adalah densitas fluida pada kedalaman $\mathrm{z}$.

Semakin lama sedimen akan tertimbun semakin tebal, berat batuan yang menimbun semakin meningkat dan meningkatnya tekanan/stress berpengaruh pada hubungan antar butir yang menyebabkan penyusunan kembali butir batuan sehingga menghasilkan porositas dan permeabilitas yang lebih rendah (Gambar 2). Jika kecepatan sedimentasi melebihi kecepatan keluarnya fluida dari ruang pori, atau keluarnya fluida terhalang oleh lapisan shale selama penimbunan, tekanan fluida menjadi overpressure dan justru menjadi pendukung untuk menambah beban overburden.

Total tekanan vertikal (total vertical stress) dapat diasumsikan sebagai kombinasi sebagai berat matrik batuan dan fluida dalam ruang pori yang melapisi kedalaman yang dimaksud:

$$
s(h)=g \int_{\circ}^{h} \rho(z) d z
$$

dengan $\rho(z)$ adalah densitas pada kedalaman $\mathrm{z}$ di bawah permukaan, dan $g$ adalah percepatan gravitasi. Bagian dari pem-

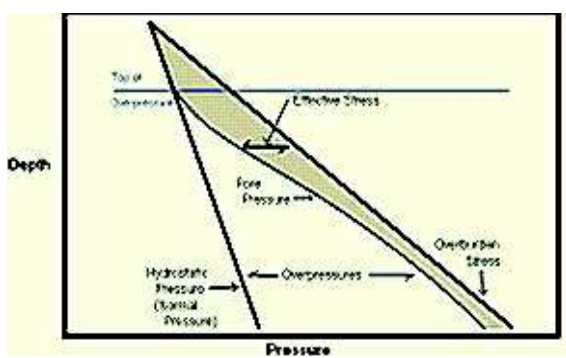

(a)

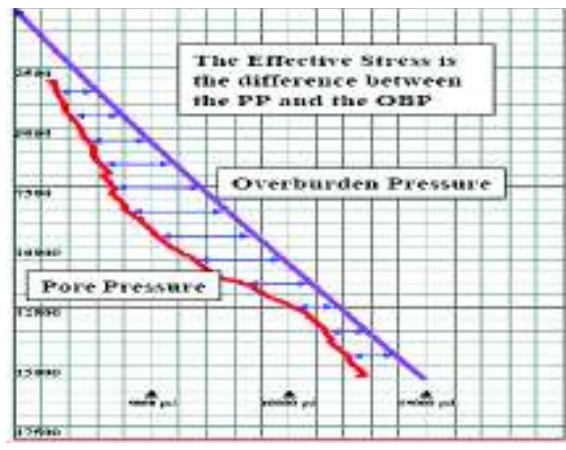

(b)

Gambar 3: (a)Diagram tekanan terhadap kedalaman sebuah sumur [1]), (b)Grafik hubungan tekanan efektif,oveburden, dan tekanan pori [2]

bebanan ini didukung oleh tekanan fluida, sementara sisanya didukung dari matrik batuan dan ini yang disebut sebagai effective stress $\sigma$ yang didefinisikan sebagai:

$$
\sigma=s-p
$$

dengan $p$ adalah tekanan fluida dan $s$ adalah total vertical stress (overburden) [1].

\section{B. Konsep Tekanan}

Gambar 3 menunjukkan sebuah diagram tekanan terhadap kedalaman untuk sebuah sumur yang mengilustrasikan beberapa konsep. Garis hydrostatic memberikan tekanan yang dihasilkan oleh kolom air. Gradien garis untuk air murni 0.433 $\mathrm{psi} / \mathrm{ft}$ tetapi biasanya untuk air formasi bernilai $0.45 \mathrm{psi} / \mathrm{ft}$ sampai $0.465 \mathrm{psi} / \mathrm{ft}\left(1 \mathrm{psi} / \mathrm{ft}=6894 \mathrm{~N} / \mathrm{m}^{2}\right)$.

Tekanan normal atau tekanan hydrostatic adalah tekanan sederhana yang dihasilkan oleh kolom air sedangkan tekanan overburden adalah tekanan yang dihasilkan oleh seluruh material yang melapisi, baik padatan maupun fluida. Di bawah water bottom, garis ini memiliki gradien yang mendekati 1 $\mathrm{psi} / \mathrm{ft}$, tetapi gradien sebenarnya bergantung pada densitas batuan dan cenderung meningkat dengan kedalaman karena densitas batuan cenderung meningkat dengan kedalaman.

Tekanan pori adalah tekanan fluida dalam ruang pori batuan. Seperti yang ditunjukkan pada Gambar 3(a), tekanan pori dapat lebih besar dari tekanan hydrostatic. Sebuah titik 


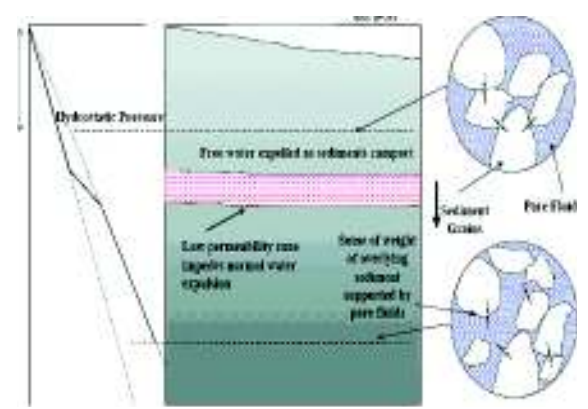

Gambar 4: Tekanan abnormal disebabkan kompaksi yang tidak merata dan terdapat zona dengan permeailitas rendah [2]

yang menunjukkan tekanan pori melampaui tekanan hydrostatic disebut dengan puncak overpressure. Dalam kondisi overpressure fluida terjebak di dalam pori-pori dan terbebani oleh berat padatan yang melapisi.

Terdapat dua definisi yang ditunjukkan pada Gambar 3(a). Pertama, besarnya tekanan pori yang melampaui garis hydrostatic disebut overpressure. Definisi kedua adalah tekanan efektif (effective stress) yang merupakan selisih antara tekanan overburden dan tekanan pori.

Konsep lain dalam Gambar 3 menyatakan bahwa tekanan pori tidak mencapai tekanan overburden. Jika tekanan pori mendekati tekanan overburden, rekahan fracture dalam batuan terbuka dan melepaskan fluida dan tekanan. Ketika tekanan pori normal, tekanan efektif meningkat dengan kedalaman. Hal ini ditunjukkan oleh $\log$ sonic, density dan resistivity pada formasi dengan tekanan normal yang meningkat terhadap kedalaman. Variasi sifat batuan di bawah kondisi tekanan normal disebut "tren kompaksi normal" (normal compaction trend.

\section{Mekanisme Overpressure}

Mekanisme overpressure dapat didekati melalui tiga kelompok utama: mekanisme pembebanan (loading), mekanisme unloading, dan tekanan tektonik. Biasanya lebih dari satu kelompok mekanisme yang terdapat dalam satu cekungan atau sumur (Gambar 4).

\section{Teori Rekahan}

Sebuah formasi dapat dipecahkan dengan mengaplikasikan tekanan fluida untuk memecah bidang. Normalnya, keretakan akan diperluas dalam arah vertikal terhadap least principal stress. Yang mana dari ketiga tekanan, yang terkecil dapat diprediksi dari aktivitas retakan yang terdapat pada area tersebut.

Patahan Normal mengindikasikan bahwa least principal stress adalah horizontal dan diperkirakan memiliki nilai yang sama terhadap tekanan minimum horizontal, hal ini dibutuhkan untuk menghindari rock failure. Patahan Thrust reverse mengindikasikan least principal stress menjadi sebuah

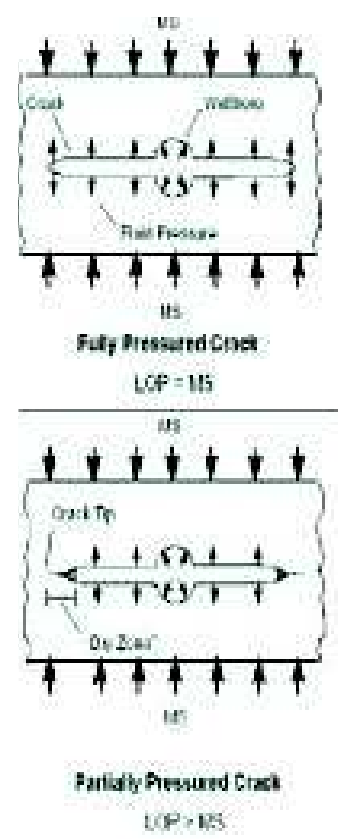

Gambar 5: Teori arah retakan

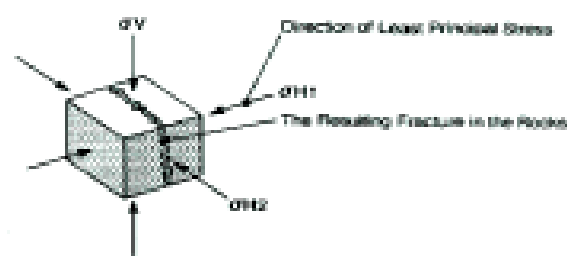

Gambar 6: Distribusi bidang tekanan dalam satu unit formasi batuan

vertical nature. Hal ini setidaknya pasti memiliki nilai sama dengan berat dari overburden, atau sekitar 1 psi/ft. Patahan Transcurrent mengindikasikan bahwa arah least principal stress adalah horizontal tetapi bisa menjadi lebih besar daripada nilai minimum yang dibutuhkan untuk menghindari terjadinya failure. Namun, juga tidak dapat lebih besar daripada tekanan vertikal (Gambar 7).

Untuk mengetahui formation breakdown gradients ditentukan dengan melakukan Leak Off Test (LOT). Normalnya dilakukan setelah drilling melewati sebuah casing shoe bertujuan untuk menentukan gradien lumpur maksimum yang diijinkan untuk open hole pada sesi berikutnya. Prosedur yang umum ditampilkan sebagai berikut :

1. Pemboran melewati casing shoe dan mencapai formasi baru hingga kedalaman 15 - 20 kaki. manutup blowout preventers.

2. Naikkan tekanan permukaan hingga kenaikannya mencapai indikasi bleed off. Secara alternatif, pemompaan dapat dilakukan pada kecepatan rendah hingga bleed off.

Selama pengujian fracture, biasanya bukan hanya pada ma- 


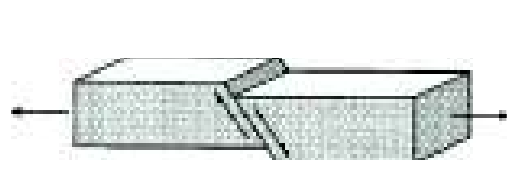

(a) Patahan Normal

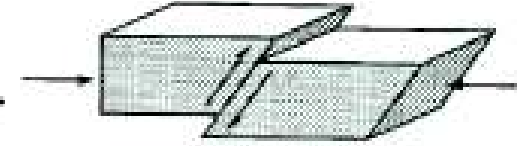

(b) Patahan Reverse

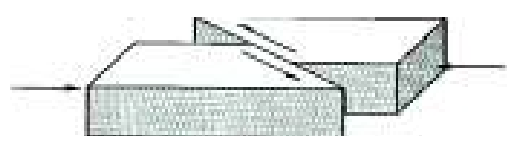

(c) Patahan Transcurrent

Gambar 7: Patahan

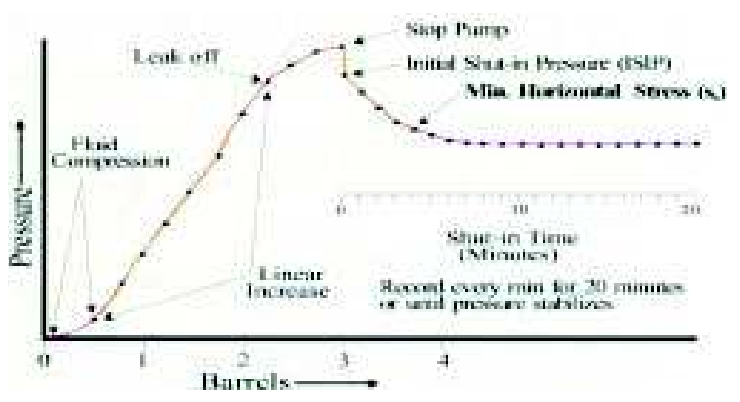

Gambar 8: Bentuk ideal uji Leak Off [1]

trik batuan yang sama/berhubungan yang digeser, tetapi lebih pada diskontinyuitas alami yang sudah ada (joints, parting, etc) yang mana pada umumnya dipengaruhi secara bersamaan oleh tekanan compressive di dalam formasi. Ketika takanan hydraulic dalam lubang bor sama dengan tekanan compressive formasi, maka hal ini akan secara efektif mengurangi tekanan compressive menjadi nol di sepanjang retakan. Kemudian, jika tekanan lubang sumur (borehole) dinaikkan secara perlahan, maka fluida akan memasuki retakan.

\section{E. Metode Tekanan Minimum}

Sama halnya dengan teori rekahan dengan memanfaatkan least principal stress yang telah dijelaskan sebelumnya, pada metode tekanan minimum ini merupakan metode yang memanfaatkan uji leak-off dalam proses pemboran (Gambar 8) untuk mengetahui nilai tekanan minimum in-situ yang dibutuhkan untuk membuat rekahan awal pada dinding sumur bor. Dengan demikian, dapat diestimasi besar tekanan yang aman untuk diaplikasikan pada berat lumpur yang digunakan sehingga tidak melebihi batas tekanan rekahan pada dinding sumur untuk menghindari terjadinya bahaya yang lebih besar seperti loss circulation.

Semua metode tegangan minimum yang dipertimbangkan pada proposal ini berdasarkan persamaan umum berikut:

$$
F G=K(O B-P P G)+P P G
$$

dengan $\mathrm{FG}=$ gradien rekah, $\mathrm{OBG}=$ gradien overburden, $\mathrm{PPG}$ = gradien tekanan pori, $\mathrm{K}=$ rasio tegangan efektif atau koefisien tegangan matrika. $\mathrm{K}$ dapat dikalibrasikan dengan $\mathrm{FG}$ yang terukur pada uji kebocoran menggunakan hubungan

$$
K=\frac{F G-P P G}{O B G-P P G}
$$

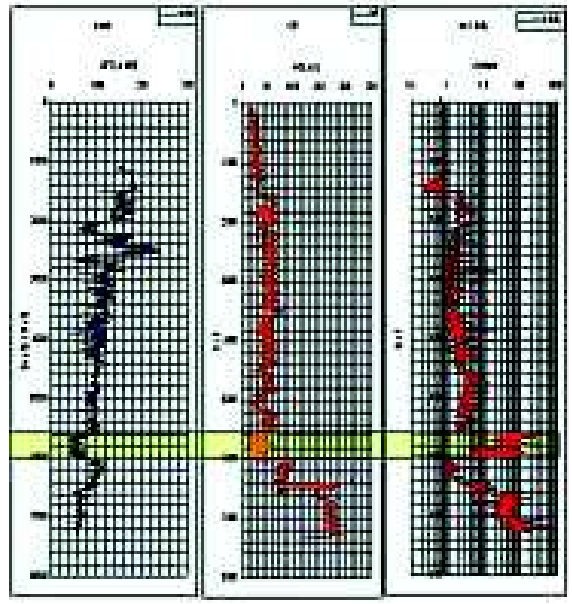

Gambar 9: Grafik log Sonic-GR-Resiativity sumur 1. Zona kuning adalah daerah dugaan hidrokarbon

Pada metode ini diasumsikan bahwa mud losses signifikan akan terjadi ketika tekanan dalam lubang sumur (wellbore) sama dengan tekanan minimum in situ.

\section{METODOLOGI}

Penelitian ini dilakukan pada lapangan NN\#. Pada penelitian ini digunakan metode tekanan efektif untuk mengestimasi nilai tekanan pori dan metode tekanan minimium untuk mengestimasi tekanan rekah. Selanjutnya, hasil dari estimasi tekanan pori dikalibrasikan dengan RFT dan/atau DST, sedangkan hasil tekanan rekah dikalibrasi dengan FIT dan/atau LOT.

Penelitian ini menggunakan data log openhole dari tiga sumur di lapangan NN\#. Log yang digunakan, baik pada perhitungan tekanan pori maupun tekanan rekah adalah log sonic. Sedangkan log-log dasar yang digunakan sebagai informasi dalam interpretasi adalah log Gamma Ray, Density Neutron, Resistivity, Caliper, dan Sonic.

Perangkat lunak (software) yang digunakan dalam proses pengolahan data adalah Presgraf, dan Microsoft Excel. 


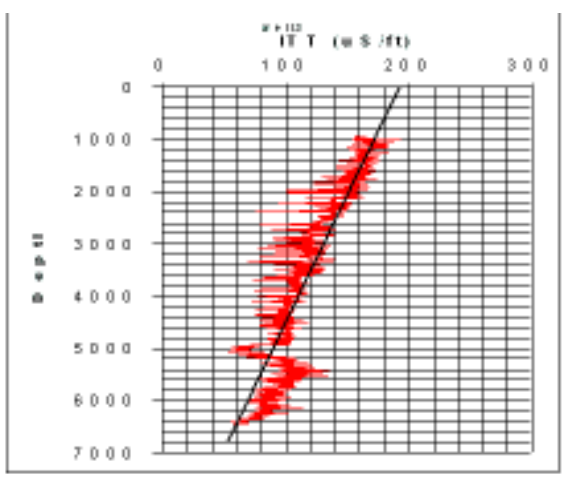

Gambar 10: Grafik log sonic Interval Transite time sumur 3

\section{HASIL DAN PEMBAHASAN}

\section{A. Analisa Data Tekanan Pori}

Dalam proses estimasi tekanan pori, digunakan metode tekanan efektif milik Eaton dan Weakley yang memiliki kemiripan dalam penggunaan eksponen.

1. Metode Eaton

Metode Eaton adalah sebuah pendekatan effective stress $(\sigma)$ yang dihitung dengan persamaan:

$$
\sigma=\sigma_{\text {norm }}\left(\frac{v}{v_{\text {norm }}}\right)^{3}
$$

dengan $v$ adalah kecepatan yang terukur, $\sigma_{\text {norm }}$ dan $\mathrm{v}_{\text {norm }}$ adalah effective stress dan kecepatan pada kondisi tekanan normal. Pada metode ini, umumnya digunakan nilai eksponen $=3$. Namun, nilai tersebut merupakan nilai untuk daerah Gulf Of Mexico, sehingga perlu dilakukan perhitungan untuk menentukan nilai eksponen pada setiap daerah. Berikut ditampilkan salah satu perhitungan menggunakan data sumur 3 .

Melalui Gambar 10 dapat diketahui nilai $\mathrm{V}_{\text {normal }}$ ataupun $\Delta \mathrm{t}_{\text {normal }}$, untuk mendapatkan nilai eksponen eaton. Langkah selanjutnya adalah mencari hubungan antara tekanan efektif dan velocity atau tekanan efektif - interval transite time $(\Delta t) / I T T$, seperti ditunjukkan Gambar 11, sehingga didapatkan persamaan $\Delta \mathrm{t}=2857,5 \sigma^{-0,4334}$, atau menggunakan Pers.6 didapat $\Delta \mathrm{t}=\mathrm{C} \sigma^{-1 / n}$ dengan

$$
-\frac{1}{n}=-0,4334
$$

sehingga nilai eksponen Eaton untuk sumur 3 adalah $\mathrm{n}_{3}$ $=2,3$ dan persamaan Eaton untuk sumur 3 menjadi:

$$
\sigma=\sigma_{\text {norm }}\left(\frac{\Delta t_{\text {normal }}}{\Delta t}\right)^{2,3}
$$

Cara yang sama dilakukan pada sumur 1 dan sumur 2 dengan nilai eksponen Eaton $\mathrm{n}_{1}=1,87$ dan $\mathrm{n}_{2}=2,287$.

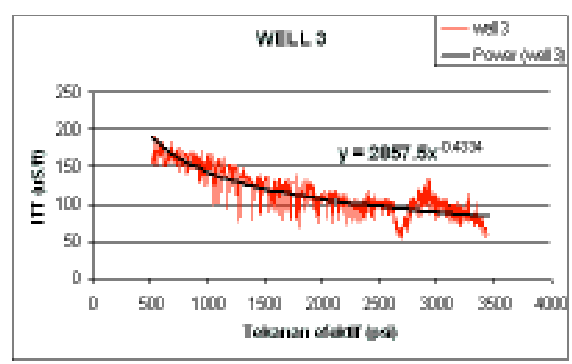

Gambar 11: Grafik hubungan ITT dan Tekanan efektif sumur 3

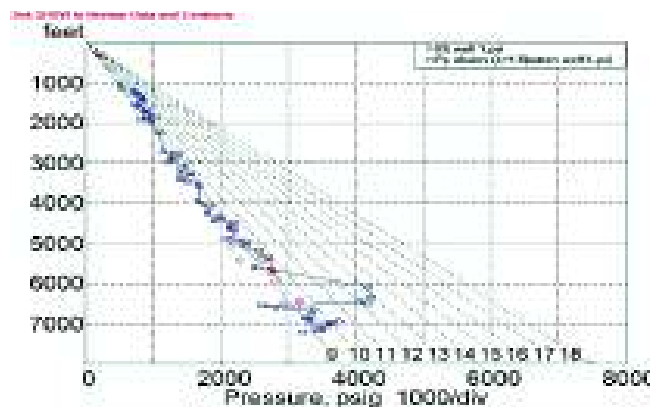

(a) Sumur 1

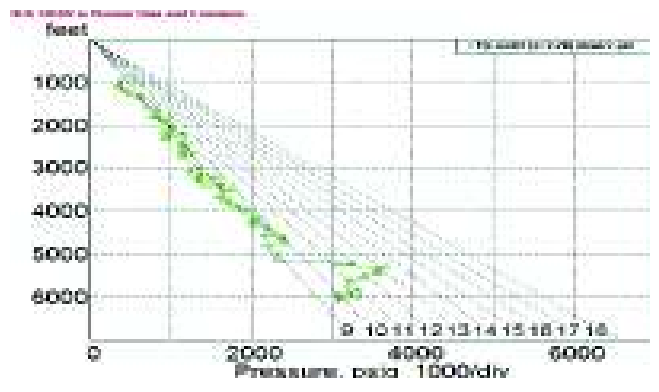

(b) Sumur 2

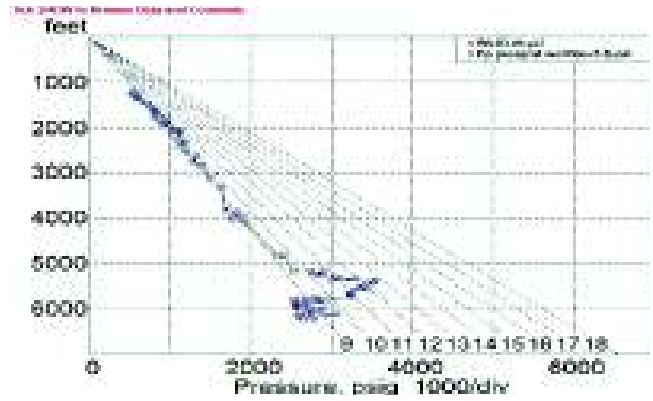

(c) Sumur 3

Gambar 12: Nilai tekanan pori sumur dengan eksponen Eaton $\mathrm{n}_{1}=1,87 ; \mathrm{n}_{1}=2,287 ; \mathrm{n}_{1}=2,3$

Grafik hasil perhitungan dengan menggunakan tekanan pori metode Eaton, ditunjukkan Gambar 12.

\section{Metode Weakley}

Pada metode yang digunakan oleh Weakley merupakan metode kelanjutan dari metode yang digunakan oleh 
TABEL I: Data RFT/DST pada sumur 3

\begin{tabular}{lcc}
\hline \hline Depth $(\mathrm{ft})$ & Depth $(\mathrm{m})$ & Press. (Psi) \\
\hline 5843.46 & 1781 & 2536 \\
5932.05 & 1808 & 2541 \\
5955.02 & 1815 & 2560 \\
6037.04 & 1840 & 2571 \\
6119.07 & 1865 & 2609 \\
6243.74 & 1903 & 2657 \\
\hline \hline
\end{tabular}

Eaton, hanya saja Weakley menawarkan suatu persamaan baru untuk menentukan nilai eksponen Eaton dengan memperhitungkan litologi yang ada pada setiap segmen lapisan demi menjamin kesinambungan dari tren velocity sehingga nilai eksponen yang didapatkan oleh Weakley dapat diaplikasikan pada semua sumur selama masih berada dalam suatu litologi yang sama.

Persamaan yang diberikan oleh Weakley (1991) untuk mendapatkan nilai eksponen Eaton adalah:

$$
N=\left(\frac{\log \left[\frac{O B-P}{O B-P_{n}}\right]}{\log \left[\frac{V}{V_{n}}\right]}\right)
$$

dengan $\mathrm{N}$ adalah eksponen Eaton, $\mathrm{OB}$ adalah tekanan overburden, $\mathrm{P}$ adalah tekanan pori yang diketahui dari DST/RFT, V adalah velocity pada kedalaman yang dimaksud. $\mathrm{P}_{n}$ dan $\mathrm{V}_{n}$ adalah nilai tren normal untuk tekanan pori.

Contoh perhitungan dengan data pada Tabel 1:

Kedalaman $=5843,5$ feet

Tekanan Overburden $=5843,5 \mathrm{psi}$

$$
\begin{aligned}
\mathrm{V}_{\text {normal }} & =11595,7 \mathrm{feet} / \mathrm{s} \\
\mathrm{V}_{\text {observasi }} & =11890 \mathrm{feet} / \mathrm{s}
\end{aligned}
$$

Tekanan pori normal $=2717,228 \mathrm{psi}$

Tekanan pori in-situ $=2536 \mathrm{psi}$

maka,

$$
\begin{aligned}
N & =\left[\frac{\log \left(\frac{5843,5-2536}{5843,5-2717,228}\right)}{\log \left(\frac{11890}{44595,7}\right)}\right] \\
& =2,25
\end{aligned}
$$

sehingga didapatkan nilai eksponen Eaton sebesar 2,248 . Nilai eksponen ini dapat diaplikasikan pada semua sumur yang ada, sehingga didapatkan hasil seperti ditunjukkan Gambar 13.

\section{B. Analisa Data Tekanan Rekah}

Pada estimasi gradien rekahan menggunakan metode tekanan minimum, merupakan tekanan terkecil yang dibutuhkan untuk memecah dinding formasi sumur. Metode tekanan minimum ini dibagi menjadi :

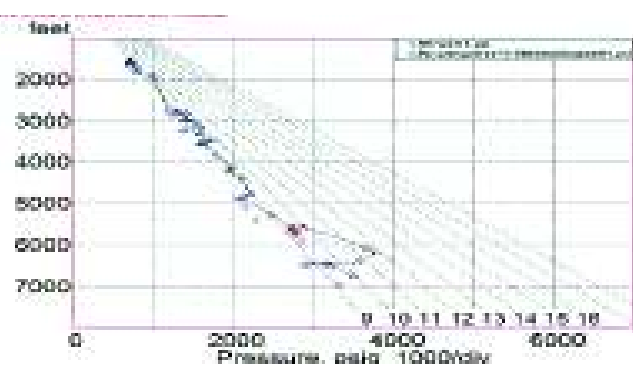

(a) Sumur 1

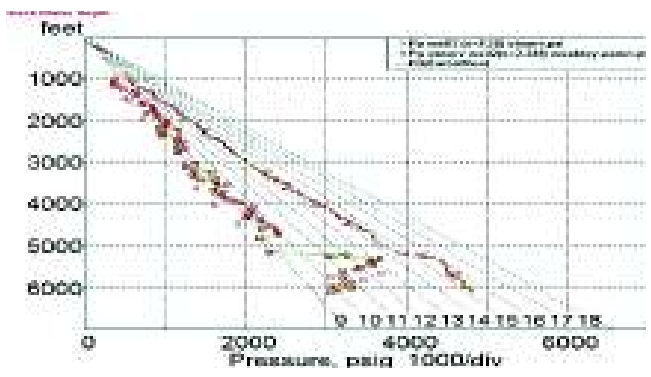

(b) Sumur 2

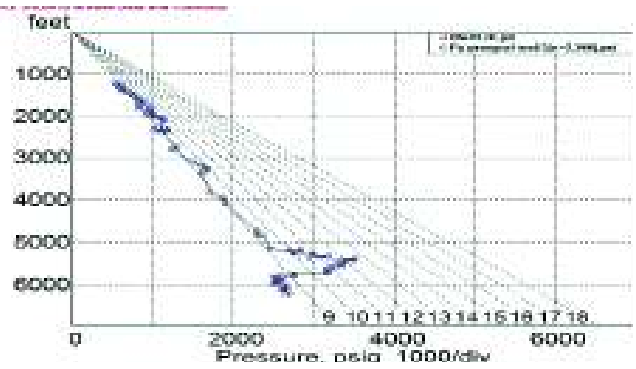

(c) Sumur 3

Gambar 13: Nilai tekanan pori sumur melalui perhitungan dengan $\mathrm{n}=2,248$ dengan metode weakley

1. Metode Hubbert \& Willis Teori sudut retakan $30^{\circ}$ digunakan $\mathrm{H} \& \mathrm{~W}$ untuk menentukan besarnya nilai rasio tekanan efektif $(\mathrm{K})$ sehingga didapatkan nilai K sebesar 0,33. Hasil yang didapatkan ditunjukkan Gambar 14

2. Metode Eaton Pada metode Eaton, teknik yang digunakan dalam penentuan nilai rasio tekanan efektif $(\mathrm{K})$ adalah menggunakan nilai rasio poisson dimana nilai rasio poisson ini bergantung terhadap litologi pada setiap lapisan, hasilnya ditunjukkan Gambar 15.

3. Metode Daines Pada metode Daines digunakan rasio poisson yang mirip dengan metode yang digunakan Eaton. Akan tetapi, dalam penentuan nilai rasio tekanan efektif (K), Daines menggunakan parameter tambahan $\beta$ untuk menggambarkan keadaan litologi akibat pengaruh aktivitas tektonik. Seperti contoh adanya lipatan (folding) dan patahan (faulting). Karena itu, nilai tekanan rekah yang didapatkan dari metode Daines akan bergantung pada litologi, kedalaman, dan aktivitas tektonik. Hasil yang didapatkan ditunjukkan Gambar 16. 


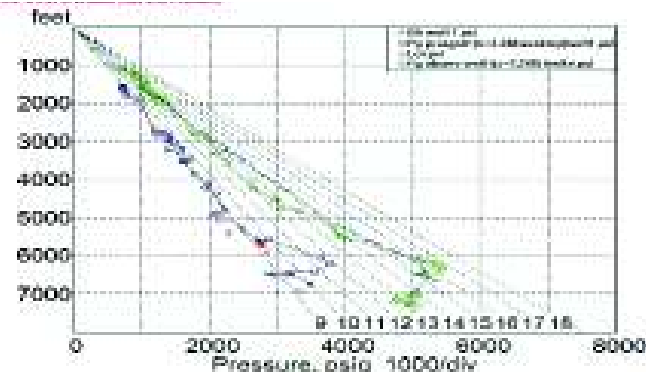

(a) Sumur 1

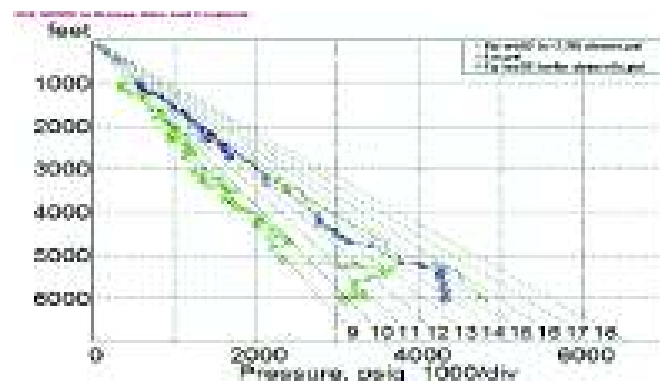

(b) Sumur 2

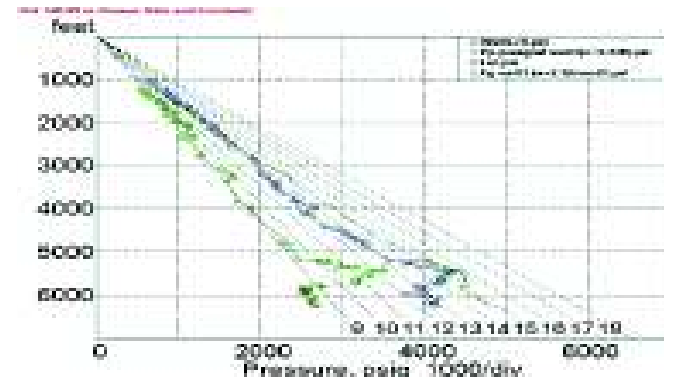

(c) Sumur 3

Gambar 14: Grafik hasil Tekanan rekah metode Hubbert \& Willis

\section{SIMPULAN}

Simpulan yang dapat diambil dari pembahasan di atas:

1. Berdasarkan data log sonic, gamma-ray, dan resistivity diperkirakan terdapat hidrokarbon dengan reservoar yang diduga berupa batuan karbonat di kedalaman 5600-6000 feet pada Sumur 1 dan kedalaman 48005200 feet pada Sumur 2 dan 3.

2. Metode Weakley umumnya mengestimasi tekanan formasi lebih rendah daripada metode Eaton sehingga Weakley dapat digunakan sebagai estimasi rendah dan Eaton sebagai estimasi tinggi.

3. Terdapat zona overpressure pada kedalaman 6000 feet pada sumur 1 dengan dengan nilai maksimum tekanan pori 13ppg. Pada Sumur 2 dan 3 ditemukan overpressure pada kedalaman 5200 feet dengan nilai maksimum 13 ppg.

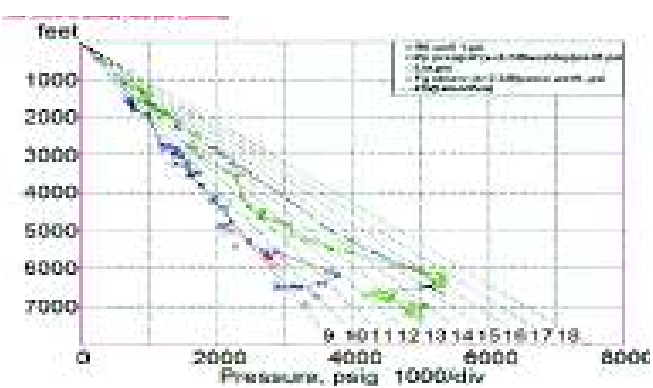

(a) Sumur 1

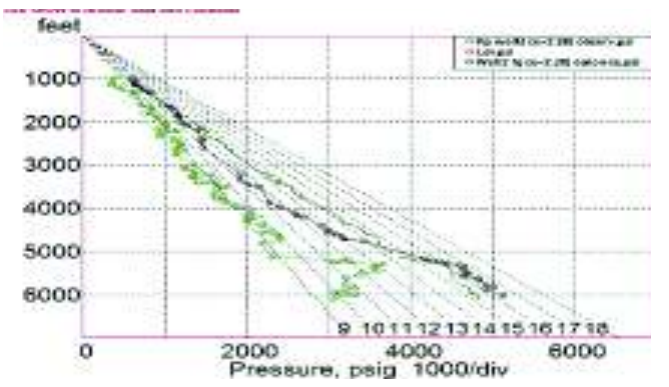

(b) Sumur 2

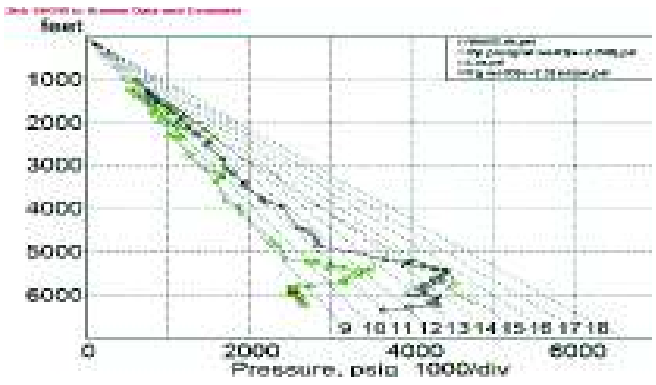

(c) Sumur 3

Gambar 15: Grafik hasil Tekanan rekah metode Eaton

4. Berdasarkan 3 sumur yang digunakan untuk sampel, estimasi dengan menggunakan metode Weakley lebih cocok pada daerah daerah/blok dimana sumur itu berada.

5. Metode Daines memiliki nilai yang lebih mendekati nilai gradien rekah hasil software Presgraf dan LOT pada daerah normal, kemudian diikuti oleh hasil dari metode $\mathrm{H}-\mathrm{W}$ yang juga cukup akurat, dan terkhir adalah metode Eaton.

6. Metode $\mathrm{H}-\mathrm{W}$ dan Eaton memiliki nilai yang mendekati nilai gradien rekah hasil software Presgraf pada daerah overpressure.

7. Pada lapangan ini, aplikasi metode Eaton mengestimasi tekanan rekah dengan nilai paling rendah dibandingkan metode $\mathrm{H}-\mathrm{W}$ dan Daines. 


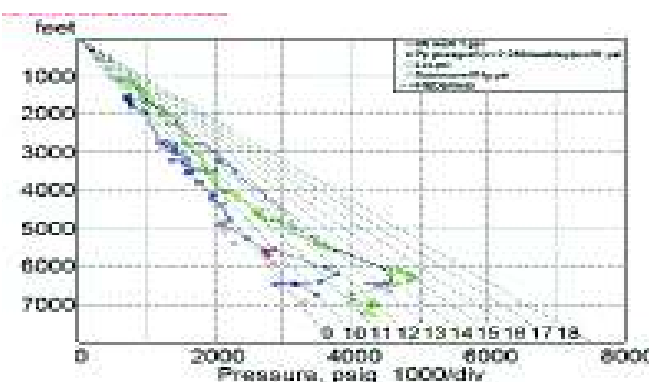

(a) Sumur 1

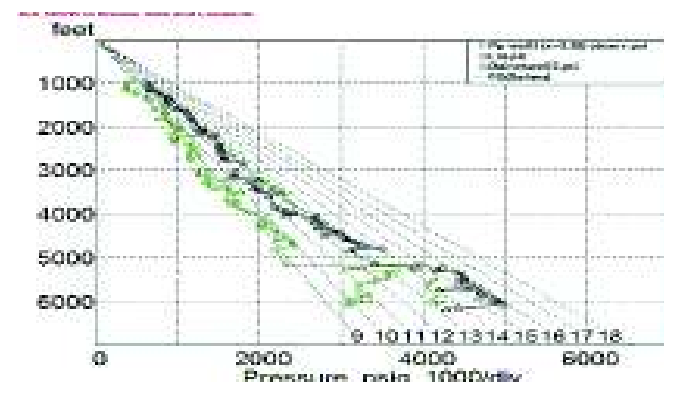

(b) Sumur 2

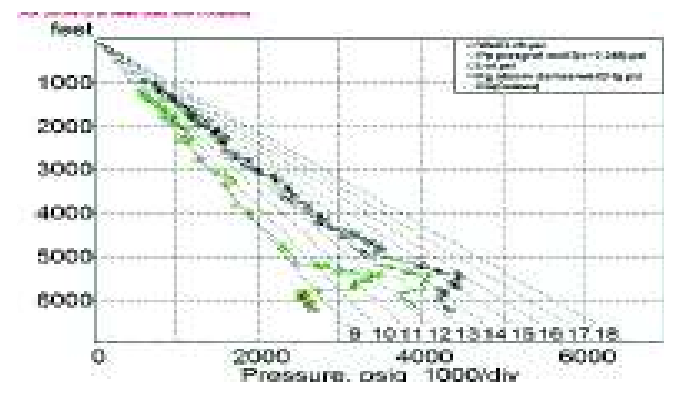

(c) Sumur 3

Gambar 16: Grafik hasil Tekanan rekah metode Daines

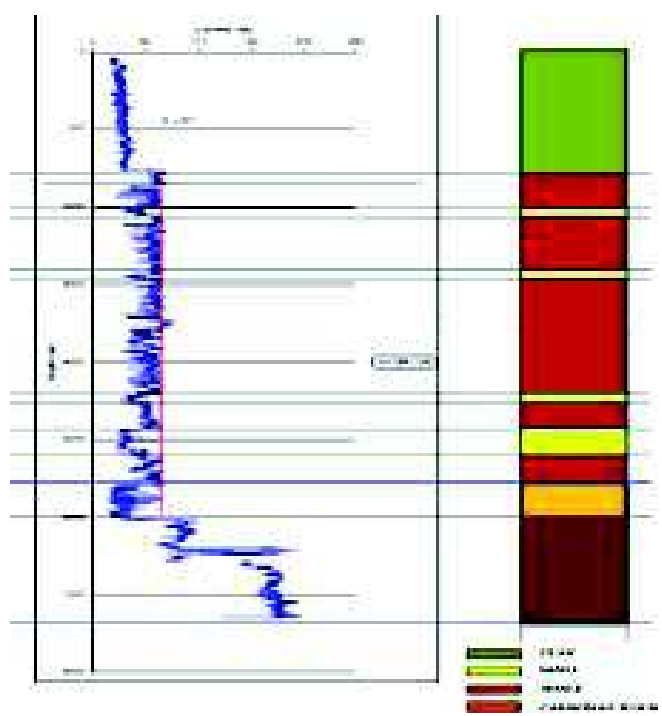

Gambar 17: Lampiran: Bentuk litologi sumur 1 dengan log Gammaray

\section{Ucapan Terima Kasih}

Kami sampaikan penghargaan setinggi-tingginya kepada para kolega dan sejawat di PT. Haliburton dan Lab. Geofisika atas kerjasamanya dalam penelitian ini. Diskusi-diskusi selama ini selalu menyenangkan dan sangat konstruktif dalam pengembangan pengetahuan dan skill di bidang ilmu kebumian.
[1] Sayers, Colin M., An Introduction to Velocity-Based Porepressure Estimation, The Leading Edge, Desember 2006, Vol. 25, No. 12 (2006)

[2] Knowledge System,Inc.,Introduction to Pore Pressure \& Fracture Gradient Theory, 2004.

[3] Knowledge System,Inc.,State of the Art in Fracture Gradient Estimation, DEA Project 199 Report No.3, August 20,1999.

[4] Knowledge System,Inc., State of the Art in Pore Pressure Estimation, DEA Project 199 Report No.1, May 25,1999.

[5] Chopra, Satinder and Alan R. Huffman, Velocity Determination for Pore-pressure Prediction, he Leading Edge, Desember 2006, Vol. 25, No. 12 (2006).
[6] SSW,Cicik, Penentuan daerah over-pressure melalui pendekatan metode Eaton dan metode Bowers, TA, Institut Teknologi Sepuluh Nopember, Surabaya, 2008.

[7] Wang, Joanne, Visualization for Pore Pressure Prediction, First Break, Volume 22, March (2004).

[8] Young, Roger A., Five Things Your Pore Pressure Analyst Won't Tell You, American Association of Drilling Engineers, 2005.

[9] Rabia,Husein, Well Engineering and construction (2004).

[10] Ben.A,Eaton, The Equation for Geopressure Prediction from Well Logs, Dallas Texas: Society Of Petroleum Engineers Of AIME, 1975. 


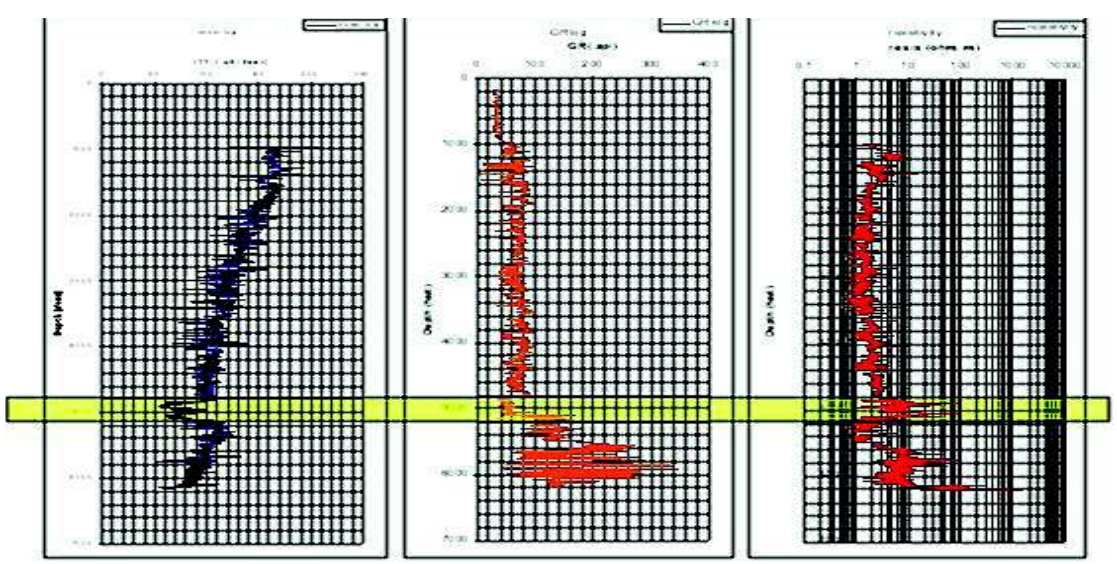

(a) Grafik log Sonic-GR-Resiativity sumur 2. Zona kuning adalah daerah dugaan hidrokarbon.

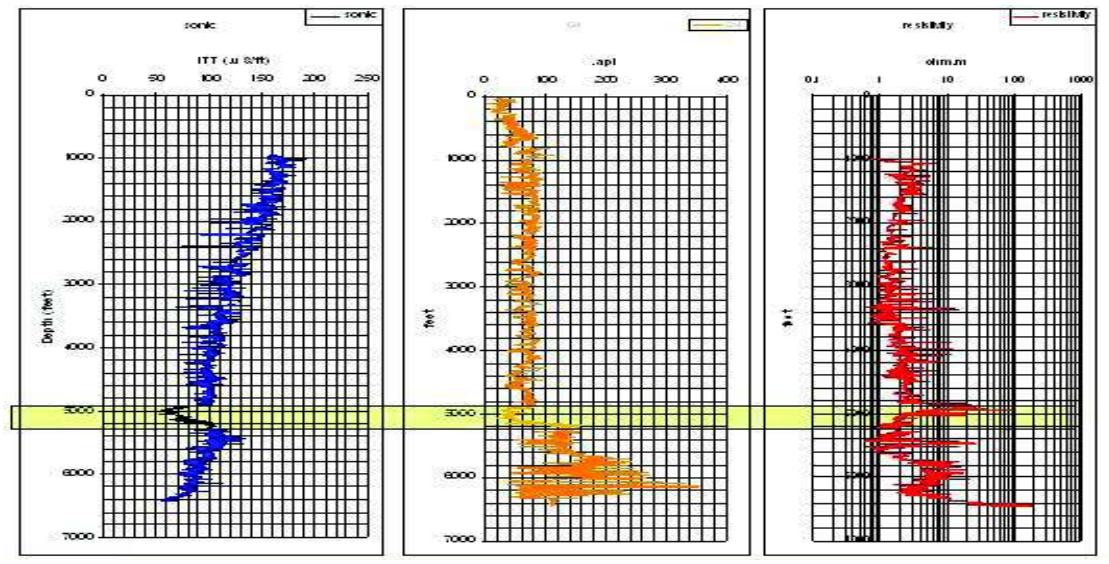

(b) Grafik log Sonic-GR-Resiativity sumur 3. Zona kuning adalah daerah dugaan hidrokarbon.

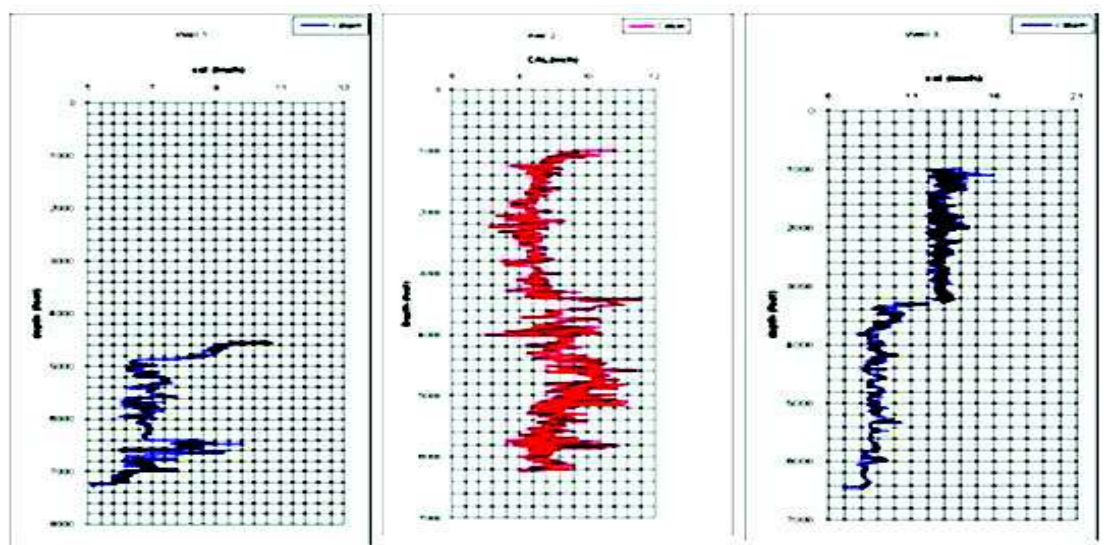

(c) Grafik log caliper pada masing-masing sumur 1, 2, dan 3

Gambar 18: Lampiran 